\title{
DA LITERATURA EM SUAS RELAÇÕES COM A LIBERDADE
}

DE LA LITTÉRATURE DANS SES RAPPORTS AVEC LA LIBERTÉ

STAËL, MADAME DE. DE LA LITTÉRATURE DANS SES

RAPPORTS AVEC LA LIBERTÉ. IN: STAËL, MADAME DE. DE LA LITTÉRATURE. 2E ÉD. PARIS: FLAMMARION, 1991, P. 76-82.

Madame de Staël

Tradução: Luiza Duarte Caetano*

Madame de Staël (1766-1817) é uma autora francesa de origem suíça, amplamente reconhecida pela historiografia literária por seu papel na difusão do romantismo na França, assim como por sua participação na Revolução Francesa e por sua oposição ao regime napoleônico. Em suas obras, destaca-se a defesa da liberdade individual, dos ideais republicanos, da perfectibilidade e da filosofia das luzes.

O excerto aqui traduzido faz parte da introdução (Discours préliminaire) de uma de suas obras mais difundidas, De la littérature considérée dans ses rapports avec les institutions sociales (Da literatura considerada em suas relações com as instituições sociais), publicada em 1800 , pouco depois do golpe do 18 de Brumário.

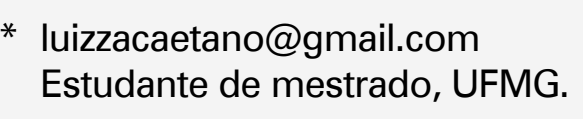

A liberdade, a virtude, a glória e as luzes, ${ }^{1}$ esse cortejo imponente do homem em sua dignidade natural, essas ideias aliadas entre si e cuja origem é a mesma, não saberiam existir isoladamente. O complemento de cada uma está na união de todas. As almas que se comprazem em associar o destino do homem a um pensamento divino veem, nesse conjunto, nessa relação íntima entre tudo o que é bom, uma prova a mais da unidade moral, da unidade de concepção que dirige este universo.

O progresso da literatura, isto é, o aperfeiçoamento da arte de pensar e de se exprimir, é necessário ao estabelecimento e à conservação da liberdade. É evidente que as luzes são tanto mais indispensáveis em um país, quanto o papel dos cidadãos que nele habitam é imediato sobre a ação do governo. Mas o que é igualmente verdadeiro é que a igualdade
1. O termo luzes [/umières] faz referência à filosofia dita iluminista do século XVIII da qual também fazem parte o Esclarecimento [Enlightenment], en] e inglês [Enightenment, entre outros, e cujos principais representantes na França foram escritores como Montesquieu. 
política, princípio inerente a toda constituição filosófica, só pode subsistir quando se classificam as diferenças de educação com ainda mais cuidado do que o feudalismo empregava nas distinções arbitrárias. A pureza da linguagem, a nobreza das expressões, as imagens do orgulho da alma são necessárias sobretudo em um estado fundado sobre as bases democráticas. Em outro contexto, certas barreiras factícias impedem a confusão total das diversas educações, mas quando o poder repousa apenas na suposição do mérito pessoal, quanto interesse não deve haver em conservar nesse mérito todas as suas características exteriores!

Em um estado democrático, é preciso temer incessantemente que o desejo de popularidade leve à imitação dos modos vulgares, do contrário, logo nos persuadiríamos de que é inútil e quase prejudicial ter uma superioridade demasiadamente marcada em relação à multidão que se quer cativar. $\mathrm{O}$ povo se acostumaria a escolher magistrados ignorantes e grosseiros, esses magistrados abafariam as luzes e, por um círculo inevitável, a perda das luzes levaria à escravidão do povo.

É impossível que, em um estado livre, a autoridade pública se dispense do consentimento verdadeiro dos cidadãos que governa. O raciocínio e a eloquência são os elos naturais de uma associação republicana. O que poderia ser feito sobre a vontade livre dos homens sem essa força, essa verdade de linguagem que penetra nas almas e inspira-lhes aquilo que ela exprime? Quando os homens chamados a dirigir o estado não têm o segredo de persuadir os espíritos, a nação não se esclarece, e os indivíduos conservam, sobre todas as questões públicas, a opinião que o acaso fez nascer em suas cabeças. Um dos principais motivos para lamentar a perda da eloquência é que isso isolaria os homens entre si, deixando-os entregues unicamente a suas impressões pessoais. É preciso oprimir quando não se sabe convencer. Em todas as relações políticas entre governantes e governados, uma qualidade a menos exige uma usurpação a mais.

Novas instituições devem formar um espírito novo nos países que se quer tornar livres. Mas como é possível fundar qualquer coisa sobre a opinião sem o socorro dos escritores distintos? É preciso fazer nascer o desejo no lugar de ordenar a obediência, e mesmo quando, com razão, o governo almeja que certas instituições sejam estabelecidas, ele deve dispor suficientemente a opinião pública para parecer conceder o que ela deseja. Apenas os escritos bem-feitos podem, em longo prazo, dirigir e modificar certos hábitos nacionais. O homem tem, no segredo de seu pensamento, um asilo de liberdade impenetrável à ação da força. Os conquistadores frequentemente adotaram os costumes dos vencidos: somente a convicção mudou os antigos costumes. É por meio do progresso da literatura que se pode combater com eficácia os velhos preconceitos. Os governos, nos países que se tornaram livres, precisam, para destruir os antigos erros, 
2. Nota da autora: Perguntaram-me que definição eu dou à filosofia de que me servi diversas vezes ao longo desta obra. Antes de responder a essa questão, permitam-me transcrever aqui uma nota de Rousseau, no segundo livro de seu Emílio: “Eu refleti cem vezes, ao escrever, sobre como é impossível, em uma obra longa, dar sempre o mesmo sentido às palavras. Não há nenhuma língua suficientemente rica para fornecer tantos termos, voltas e frases quanto nossas ideias podem ter em modificações. O método de definir todos os termos e substituir incessantemente a definição, no lugar do definido, é belo, mas impraticável, pois como evitaríamos assim o círculo? As definições seriam boas, se não empregássemos palavras para fazê-las. Apesar disso, estou persuadido de que é possíve ser claro, mesmo na pobreza da nossa língua, não ao dar sempre as mesmas acepções às mesma palavras, mas sim ao fazer com que, tantas vezes quantas forem que, tantas vezes quantas for
empregadas cada palavra, a acepção dada seja suficientemente determinada pelas ideias que a ela se relacionam, e que cada período em que essa palavra cada periodo sirva-lhe, por assim dizer, de definição." >>> do ridículo que deles afasta os jovens e da convicção que deles distancia a idade madura, eles precisam, para fundar novos estabelecimentos, excitar a curiosidade, a esperança, o entusiasmo, enfim, os sentimentos criadores que deram à luz tudo o que existe, tudo o que perdura, e é na arte de falar e de escrever que se encontram os únicos meios de inspirar esses sentimentos.

A atividade necessária a todas as nações livres é exercida pelo espírito de facção quando a expansão das luzes não é objeto do interesse universal, quando essa ocupação não apresenta uma carreira aberta a todos, que possa excitar a ambição generalizada. Além disso, é preciso um estudo constante da história e da filosofia para aprofundar e propagar o conhecimento dos direitos e dos deveres dos povos e de seus magistrados. A razão só serve, nos impérios despóticos, à resignação individual, mas nos estados livres, ela protege o repouso e a liberdade de todos.

Entre os diversos desenvolvimentos do espírito humano, é a literatura filosófica, é a eloquência e o raciocínio que eu considero como a verdadeira garantia da liberdade. As ciências e as artes são uma parte muito importante dos trabalhos intelectuais, mas suas descobertas e seu sucesso não têm influência imediata sobre a opinião pública que decide o destino das nações. Os geômetras, os físicos, os pintores e os poetas receberiam incentivos no reino de reis todo-poderosos, enquanto a filosofia política e religiosa pareceria a tais mestres a mais ameaçadora das insurreições.

Aqueles que se entregam ao estudo das ciências positivas, não encontrando em seu caminho as paixões dos homens, acostumam-se a contar apenas com o que é susceptível de demonstração matemática. Os cientistas classificam quase sempre entre as ilusões aquilo que não pode ser submetido à lógica do cálculo. Eles avaliam antes a força do governo, qualquer que ele seja, e como não têm outro desejo além de se entregar em paz à atividade de seus trabalhos, tendem a obedecer à autoridade que domina. A meditação profunda que exigem as combinações das ciências exatas impede que os cientistas se interessem pelos acontecimentos da vida, e nada convém mais aos monarcas absolutos que homens tão profundamente ocupados com as leis físicas do mundo que abandonam a ordem moral a quem dela quiser se apoderar. Sem dúvida, as descobertas das ciências devem, em longo prazo, dar nova força à alta filosofia ${ }^{2}$ que julga os povos e os reis, mas esse futuro distante não assusta os tiranos: já vimos vários deles protegerem as ciências e as artes; todos temiam os inimigos naturais dessa proteção mesma, os pensadores e os filósofos.

A poesia é, de todas as artes, aquela que está mais próxima da razão, entretanto, a poesia não admite a análise nem o exame que permite descobrir e propagar as ideias filosóficas. Quem quisesse enunciar uma verdade nova e audaciosa
2. $>>>$ Depois de ter citado essa opinião de um grande mestre contra as definições, direi que não dou jamais à palavra filosofia, ao longo desta obra, o sentido que seus detratores quiseram dar-Ihe em nosso tempo, seja opondo-a às ideias religiosas, seja chamando de filosóficos sistemas puramente sofísticos. Eu entendo por filosofia o conhecimento geral das causas e dos efeitos na ordem da moral ou na natureza física, a independência da razão e o exercício do pensamento, enfim, na literatura, as obras ligadas à reflexão ou à análise e que não são unicamente 0 produto da imaginação, do coração ou do espírito.

\begin{tabular}{|c|c|c|c|c|c|}
\hline EM TE: & BELO HORIZONTE & v. 23 & N. 1 & JAN.-ABR. 2017 & STAËL; CAETANO. Da Literatura em suas relações com a Liberdade \\
\hline
\end{tabular}


deveria escrever, de preferência, na língua que transmite exata e precisamente o pensamento, deveria buscar antes convencer pelo raciocínio do que levar pela imaginação. A poesia consagrou-se mais frequentemente a elogiar que a censurar o poder despótico. As belas-artes, de maneira geral, podem às vezes contribuir, por suas próprias fruições, a formar sujeitos tais quais os tiranos os desejam. As artes podem distrair o espírito, pelos prazeres de cada dia, de todo pensamento dominante. Elas voltam os homens para as sensações, inspiram à alma uma filosofia voluptuosa, um descuido refletido, um amor pelo presente e um esquecimento do futuro muito favoráveis à tirania. Por um contraste singular, as artes, que nos fazem desfrutar a vida, nos tornam indiferentes à morte. Somente as paixões apegam-nos fortemente à existência, pela vontade ardente de atingir seus fins, mas essa vida consagrada aos prazeres diverte sem cativar, ela nos inclina à embriaguez, ao sonho, à morte. Nos tempos famosos por suas proscrições sanguinárias, os romanos e os franceses se entregavam aos divertimentos públicos com a mais viva disposição, enquanto nas repúblicas felizes, as afeições domésticas, as atividades sérias e o amor à glória desviam frequentemente o espírito das próprias fruições das belas-artes. A única potência literária que faz tremer todas as autoridades injustas é a eloquência generosa, a filosofia independente que julga no tribunal do pensamento todas as instituiç̃̃es e todas as opiniões humanas.
A influência grande demais do espírito militar é também um perigo iminente para os estados livres, e só se pode prevenir tal perigo pelo progresso das luzes e do espírito filosófico. O que permite aos guerreiros desdenhar os homens de letras é que seus talentos não estão sempre unidos à força $e$ à veracidade do caráter. Mas a arte de escrever seria também uma arma, a palavra seria também uma ação se a energia da alma nela se pintasse por inteiro, se os sentimentos se elevassem à altura das ideias, e se a tirania se visse assim atacada por tudo o que a condena: a indignação generosa e a razão inflexível. A consideração, então, não seria exclusivamente atribuída às conquistas militares, o que necessariamente expõe a liberdade.

A disciplina bane toda espécie de opinião entre as tropas. Nesse sentido, seu espírito corporativo [esprit de corps] tem alguma relação com o dos padres: ele exclui da mesma maneira o raciocínio ao admitir por regra única a vontade dos superiores. O exercício contínuo da onipotência das armas termina por inspirar o desprezo pelos progressos lentos da persuasão. $\mathrm{O}$ entusiasmo que os generais vencedores inspiram é completamente independente da justiça e da causa que eles apoiam. O que impressiona a imaginação é a decisão da fortuna, o sucesso do valor. Ao vencer batalhas, podemos subjugar os inimigos da liberdade, mas para fazer com que os princípios dessa mesma liberdade sejam interiorizados, é 
preciso que o espírito militar se apague, é preciso que o pensamento, unido a qualidades guerreiras, à coragem, ao ardor, à decisão, faça nascer na alma dos homens algo de espontâneo, de voluntário, que se extingue neles quando veem por muito tempo o triunfo da força. O espírito militar é o mesmo em todos os séculos e em todos os países. Ele não caracteriza a nação nem liga o povo a esta ou aquela instituição. Ele é igualmente apropriado para a defesa de todas elas. A eloquência, o amor pelas letras e pelas belas-artes e a filosofia são os únicos que podem fazer de um território uma pátria ao dar à nação que o habita os mesmos gostos, os mesmos hábitos e os mesmos sentimentos. A força se dispensa do tempo e destrói a vontade, mas por isso mesmo ela não pode fundar nada entre os homens. Repetiu-se frequentemente, durante a revolução da França, que o despotismo era necessário para estabelecer a liberdade. Ligou-se, pelas palavras, um contrassenso de que se fez uma frase. Mas essa frase não muda em nada a verdade das coisas. As instituições estabelecidas pela força imitam tudo da liberdade, exceto seu movimento natural; suas formas são como os modelos que assustam por seu realismo: neles encontramos tudo, menos a vida.

\section{REFERÊNCIAS}

BALAYÉ, Simone. Madame de Staël: lumières et liberté. Paris: Éditions Klincksieck, 1979.
LANSON, Gustave. Madame de Staël. In: LANSON, Gustave. Histoire illustrée de la littérature française. Paris: Hachette, 1923, p. 211-219. v. 2

GOULEMOT, Jean-Marie. La littérature des Lumières. Paris: Nathan Université, 2002

SOUZA, Nabil Araújo de. De Robespierre a Kant: Mme de Staël e a "Revolução Alemã" da crítica francesa. Revista Caligrama Belo Horizonte, v. 18, n. 1, p. 211-235, 2013.

VAN TIEGHEM, Paul. Introduction. In: STAËL, Madame de. De littérature considérée dans ses rapports avec les institutions sociales. Edição crítica. Paris, 1959, p. VII-LXIV.

WILHELM, Jane Elisabeth. La traduction, principe de perfectibilité, chez Mme de Staël. Translators' Journal, v. 49 n. 3, 2004, p. 692-705. Disponível em: < http://id.erudit.org/

iderudit/009387ar>. Acesso em: 15 fev. 2014. 